\title{
THE REFLECTION OF GREEN TRAINING AND DEVELOPMENT ACTIVITY ON SOCIAL RESPONSIBILITY:FIELD RESEARCHED IN THE GENERAL DIRECTORATE OF MUNICIPALITIES IN IRAQ.
}

\author{
M. A. Al-Sumaidaee, N. J. A. Al-Zeidi \\ College of Administration and Economics, Business Administration Department, Baghdad University.
}

DOI: $10.37648 / \mathrm{ijrssh.v10i03.014}$

Received: $05^{\text {th }}$ June, 2020; Accepted:28 ${ }^{\text {th }}$ June, 2020; Published: 01 ${ }^{\text {st }}$ July,2020

\begin{abstract}
The research aimed to explore the extent to which the Green Training and Development (GTD) activity reflects on Social Responsibility (SR) in the General Directorate of Municipalities (GDM) in Iraq.The searchdepends on the descriptive and analytical approach, as it is the most appropriate in human research. Therefor, the questionnaire was used as a tool to collect data and information in addition to the interview and the official documents available in the researched organization. The research community and sample contained a random sample that included senior management, section managers, administrative and technical divisions, and some employees in the GDM, with a number of (177) respondents. The available information and data, were analyzed using appropriate statistical methods such as (frequencies, percentages, mean, standard deviation, difference coefficient, Pearson correlation coefficient and simple linear regression equation) and were statistically processed by SPSS v.24 and Excel. Among the most important conclusions of the research, that the researched organization deals well with the (GTD) activity, in pursuit to prepare efficient and environmentally educated human resources. While, the impact of this activity has been moderately reflected on $(S R)$, despite the lack of knowledge and academic awareness among managers and employees of the concept of (GTD), which make a sense of the department's weak interest in this activity. So one of the practical implications of the research is to help the researched organization to upgrade the (GTD) activity of managers and employees towards a more distinctive Social Responsibility.
\end{abstract}

Keywords:Green Training and Development Activity, Social Responsibility.

\section{INTRODUCTION :}

Most service organizations aim to achieve a positive view by society and environmentally responsible for the results of their activities, and therefore they have worked to improve the performance and effectiveness of their organizations by developing the efficiency and knowledge of their human resources through green training and development, which reflects positively on society's view towards service organizations and the most important municipal institutions. Green training indicates motivating employees to acquire 
environmental protection capabilities and pay attention to environmental concerns. To achieve these environmentally sustainable results, trained, skilled human resources are required in the organization. Green training and development is an essential priority for any organization that contributes to social responsibility activities, and is indispensable for implementing successful activities related to environmental management and cleaner production. The green training and development activity can have a wide impact on individuals in the organization, because adopting an environmental approach in organizations requires an increase in the number of employees, skills, awareness and knowledge related to each of the materials and processes, and this in turn requires training in environmental management to bring inclusiveness and participation in environmental issues. Also, social responsibility is not a new concept in business philosophy and thought, it is an imperative duty for business organizations, because it is a moral obligation first and a human, religious and legal duty that is important for the recovery and welfare of societies and achieving social justice and achieving love and good reputation among people or clients.Governmental and non-governmental organizations have endeavored to consolidate this concept due to the positive returns of societies, the environment and even the economic benefit of organizations, and the level of interest in them has increased over the years. As the modern view of the concept of social responsibility confirms that the organization cannot grow and continue in a society full of social problems because it affects and is affected by society. In order to do this, a good and efficient administration must be established within the municipal institutions, with an increased view, interest and sense of social and environmental responsibility, whether for the local or national community. Which reflects in all positively on the quality of the service provided and thus reflects the ability of the organization to meet the needs of the beneficiaries of the service without harming any of the components of the surrounding environment or society.

The main research problem was the presence of a clear deficiency and lack of awareness of the importance of the availability of green training and development activities that employ and develop human resources, which is reflected in building an administration with distinct social responsibility. The importance of this research stems from the fact that it is an attractive subject in administration, and it focuses on the local Iraqi environment represented by the research community (General Directorate of Municipalities) overseeing municipal institutions in Iraq (except for the Mayoralty of Baghdad and the Kurdistan region), and the extent of this concept's contribution to achieving and creating good management have a responsible social and environmental view of the researched organization.The main objective of the research was to identify the nature and type of the correlation and impact relationship that links green training and development activities with social responsibility in the General Directorate of Municipalities and to identify the level of application of green training and development activities in the researched organization and its importance to achieve the dimensions of social responsibility, the research concluded that there is a correlation and moral effect Between the two variables of the research and their sub-dimensions, the researched organization deals moderately with these two variables in its business and administrative system, and the activities of green training and development have positively reflected on social responsibility. Figure 1 below shows the illustrative hypothetical scheme of the basic idea of the research:

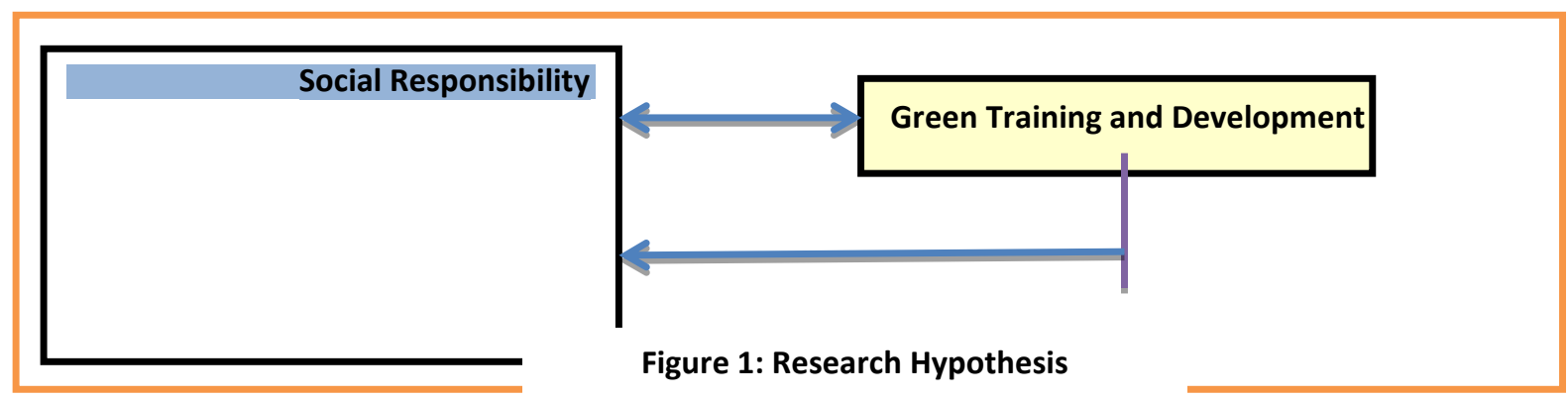

The research scope was restricted to the Ministry of Construction, Housing, Municipalities, and Public Works in Iraq. So the research community included the General Directorate of Municipalities, which is one of the formations of the 
Ministry above, as the number of its employees who are inside the workforce is 328 employees, while the research sample included (54\%) of the research community with random sample of (177) respondents. And it covered the top management, managers and heads of departments and divisions of administrative and technical departments and some employees in the General Directorate of Municipalities; As they being the target group for the research, and they have job knowledge, so that qualifies them to deal with vocabulary search. Table (1) below shows the identifying information for the research sample:

Table (1): Identification information for the research samp

\begin{tabular}{|c|c|c|c|}
\hline \multicolumn{2}{|c|}{$\begin{array}{l}\text { Identification information for the research } \\
\text { sample }\end{array}$} & \multirow{3}{*}{$\begin{array}{l}\text { Repetition } \\
103 \\
74\end{array}$} & \multirow{3}{*}{$\begin{array}{l}\text { percentage\% } \\
58.2 \\
41.8\end{array}$} \\
\hline \multirow{3}{*}{ Gender } & Male & & \\
\hline & Female & & \\
\hline & Total & 177 & $\% 100$ \\
\hline \multirow{5}{*}{ Age } & 30 years and under & 29 & 16.4 \\
\hline & $31-40$ years old & 83 & 46.9 \\
\hline & $41-50$ years old & 41 & 23.2 \\
\hline & 51 years and over & 24 & 13.5 \\
\hline & Total & 177 & $\% 100$ \\
\hline \multirow{5}{*}{ Social status } & Married & 141 & 79.7 \\
\hline & Unmarried & 26 & 14.7 \\
\hline & Divorced & 4 & 2.2 \\
\hline & widow & 6 & 3.4 \\
\hline & Total & 177 & $\% 100$ \\
\hline \multirow{7}{*}{ Qualification } & Secondary and lower & 20 & 11.3 \\
\hline & diploma & 19 & 10.7 \\
\hline & $\mathrm{BA}$ & 124 & 70.1 \\
\hline & Higher Diploma & 6 & 3.4 \\
\hline & M.A. & 8 & 4.5 \\
\hline & Ph.D. & 0 & 0 \\
\hline & Total & 177 & $\% 100$ \\
\hline \multirow{6}{*}{ Length of service } & 5 years or less & 30 & 17 \\
\hline & $6-10$ years & 53 & 30 \\
\hline & 11-15 years & 34 & 19.2 \\
\hline & $16-20$ years & 38 & 21.4 \\
\hline & 21 years and over & 22 & 12.4 \\
\hline & Total & 177 & $\% 100$ \\
\hline
\end{tabular}

The research period was determined by the period of time beginning on 15/10/2019 and ending on 1/4/2020. The descriptive analytical method was relied on thisresearch, as it is the most appropriate use in human research. Whilethe data and information collection tools and measurement tools, included:

A- The questionnaire list: It was adopted as a main tool for collecting data and information and was designed in the light of the Likert pentagon scale and was based on its preparation on some previous studies and the employment of some ready-made measures, as shown in Table (2) below:

Table (2): Reliability of dimensions and measures of search variables

\begin{tabular}{|l|l|l|l|}
\hline Paragraph & Paragraph statement & The sequence & Source \\
\hline Identifying information & $\begin{array}{l}\text { Gender, age, marital status, } \\
\text { educational qualification and } \\
\text { length of service. }\end{array}$ & Prepared by the researcher \\
\hline
\end{tabular}




\begin{tabular}{|l|l|l|l|}
\hline Greentraining and development & - & q 1-5 & (Mashala,2018) \\
\hline Social responsibility & $\begin{array}{l}\text { The economic dimension, the } \\
\text { social dimension, the } \\
\text { environmental dimension, the } \\
\text { ethical dimension, the } \\
\text { charitable dimension. }\end{array}$ & q-30 & (Tetrevova \& Jelinkova,2019) \\
\hline
\end{tabular}

In order to adopt the questionnaire to measure the research variables, it was subjected to a number of procedures, including:

1- Apparent honesty: The questionnaire paragraphs were presented in the form of an arbitration form to a number of specialized arbitrators, by (20) arbitrators. This is for the purpose of knowing the validity and apparent validity of the scale paragraphs (the questionnaire) because of their scientific and functional experience and knowledge to deal with the research question vocabulary. Some arbitrators and as a result, the questionnaire was drafted from (30) paragraphs.

2- Constructive honesty: The results of the exploratory factor analysis showed that the factorsaturation of the paragraphs of the independent variable (green training and development) is greater than (0.40) and this indicates that the data related to the independent variable are exploratory truth that is acceptable, as the highest value reached (0.693) It explains what is $(69.3 \%)$, but the lowest value is (0.630), meaning that it explains $(63 \%)$, and thus it becomes clear that the scale is valid for use. While the results of the exploratory factor analysis showed that the factorsaturation of the paragraphs of the dependent variable (social responsibility) is greater than (0.40) and this indicates that the data related to the dependent variable are exploratory validity that is acceptable, as the highest value reached (0.791), meaning that it explains what percentage (79.1). As for the lowest value, it reached (0.599), meaning that it explains its ratio $(59.9 \%)$. Thus, it becomes clear that the scale is valid for use.

3- The stability of the questionnaire: The value of (Cronbach's Alpha) for the dimensions of the independent and dependent variables were all higher than the minimum of $(0.60)$ and by evaluating the stability of the variables and their dimensions (very good), the value of (Cronbach's Alpha) for the green training and development variable $(0.862)$. While the values of the dimensions of the social responsibility variable $(0.874$, for the economic dimension), $(0.877$, for the social dimension), $(0.896$, for the environmental dimension), (0.895, for the ethical dimension) and (0.875, for the charitable dimension) and the total value of the dependent variable was (0.964). So, the value of (Cronbach's Alpha) for the total resolution data reached (0.974) and with a rating of stability (very good), this indicates the intensity of the scale stability.

B- The official interviews and documents available in the researched organization: The researcher conducted a

number of interviews with a number of the managers of the researched organization to define the research variables and their sub-dimensions and the extent of their application in the Directorate's work and the importance of real and accurate answer to the paragraphs of the questionnaire, in addition to the use of official documents of the Directorate to identify the structure Organizational and staff numbers in the Directorate.

The researcher also relied on entering and analyzing data on the SPSS v.24 software package and the Excel program. The most important statistical tools used in the practical aspect of the research are:

1- Arithmetic mean: for the purpose of determining the level of the answer to the questionnaire paragraphs.

2- Standard deviation: to know the level of dispersion of the sample responses around the mean.

3- Difference coefficient: to determine the importance of research variables.

4- Pearson correlation coefficient: to determine the type of response or explanatory relationship between research variables.

5- Simple linear regression: to measure the effect of the independent variable on the dependent

variable. 


\section{LITERATURE REVIEW:}

\section{2-1- green training and development:}

2-1-1- The concept of green training and development: The environmental training for members of the organization, including employees and managers,provide the skills and knowledge required regarding greening to increase environmental awareness by learning green best practices (Mahdi, 2018: 49). In order to ensure the effectiveness of green training, it should be planned in line with the nature of the targeted jobs (Skarna, 19: 2017). An environmental approach requires increasing employee awareness, skills, and practical knowledge, and training and development are essential elements in implementing green human resource management (Al-Zubaidi, 2016: 62). Effective implementation of social responsibility requires green training, because green training plays a crucial role in entering green information to support changes in the social responsibility of organizations in business processes (Al Kerdawy, 2018: 4).Moreover, when training and development extends to newly appointed employees in the form of an introductory list, it directs and gives more commitment from employees towards environmental management (Mashala, 2018: 62). Green training and development can be defined as "a set of practices that direct the greatest attention towards developing employee skills and learning knowledge that provides them with environmentally acceptable methods of work such as waste minimization, proper use of resources, and energy conservation as it provides an opportunity for employees to contribute to solving environmental problems and encourage them to reach New ideas that reduce environmental degradation" (Tiwari\&Bangwal, 2015: 48). It also means equipping employees with the basic skills to raise environmental literacy level (Jabbar \& Abid, 2015: 46).

2-1-2- The importance of green training and development: Green training and development is a primary priority for any organization because it contributes to sustainable development and environmental responsibility (Pinzone et al., 2019). Moreover, it is indispensable for the implementation of successful activities related to environmental management and cleaner production. Adopting an environmental approach in organizations requires an increase in staff, skills, awareness and knowledge related to both materials and processes; This in turn requires training in environmental management to generate knowledge and know-how on environmental issues. Therefore, developing employee capabilities is central to environmental and social responsibility, and it will also help encourage employee commitments to environmental goals (Mousa \& Othman, 2019: 11). Also, green environmental training is one of the most important tools for developing human resources and facilitating the transition to a more sustainable society by achieving these two goals: (1) Educating employees on the environmental policy of the organization. (2) Change the employee's individual behavior to be more aware of the relationship with the environment (Teixeira et al., 2012,321).

2-1-3-Green Training and Development activities and programs: (Jain, 2016) study believes that personnel training and development programs should include social and environmental issues at all levels, starting with considerations related to occupational health and safety, and strategic sustainability issues at the level of the executive management and the board of directors. And to cover a full range of social, environmental and economic risks and opportunities involved in business.In addition to informing workers about green procedures and policies including the organization's vision and mission, sustainabilityoriented benefits, and organization-wide initiatives such as greenhouse gas reduction, green product creation and waste management (in terms of prevention and reduction), and training of frontline staff to analyze And sorting waste from their fields of work, as well as the establishment of green teams in each department, which leads to public awareness and private training (Ismail and Bardan, 5: 2017).Organizational change activities to manage green problems often use education programs that reveal green practices and transmit the organization's values to notify individuals of needed change through an early pursuit of environmental protection. This individual behavior can be shaped by basic methods of intervention. These methods guide the teaching and motivation philosophy of learning, development, and organizational change. Green training refers to a blueprint for events that motivate workers to gain environmental protection capabilities and pay attention to environmental concerns (Shah, 2019: 3).Therefore, an essential and good condition for organizations to achieve these environmentally sustainable results is trained and skilled green human resources (Abdul Moktadir et al., 2019: 2). Environmental sustainability involves a robust development of policies and systems including training of employees at all levels of the organization. In this case, staff training and development programs 
should intentionally involve aspects of environmental management. When the Human Resources Management Department requests an analysis of training needs, the environmental base gaps for staff knowledge and skills must be taken into account to bring in informed decisions of environmental training for employees.It is essential that training and development programs include seminars and workshops to enable and acquire employees with knowledge and skills related to environmental management so that they can change their behavior and protect the environment. Also, environmental aspects related to safety, energy, waste management and recycling should form an essential part of employee training programs (Mashala, 2018: 62).

2-1-4- Green Training and Development Steps: The green training and development process includes the following as defined (Teixeira et al., 2016: 3):

A- Analyzing the gaps and training needs of the responsibilities and duties of green activities.

B- And the use of external sources if there are no trainers inside the organization.

C- Allocating the appropriate financial accreditation and preparing the necessary materials to communicate green ideas and knowledge to the employees.

D- Conducting an evaluation of the employee'sperformance in the training courses and determining their satisfaction with the green training programs.

E-Determine the employee's ability to apply green practices in daily work activities.

\section{2-2- social responsibility}

2-2-1- The concept of social responsibility: (Harrold Bowin, 1953) referred to social responsibility as "the obligations of businessmen to follow policies, make those decisions, or follow lines of action that are desired in terms of the goals and values of society" (Formankova et al., 2019 3), and that social responsibility is explicitly or implicitly linked to the ethics of administration (Manhal and Al-Karawi, 2019: 96-97). Also, social responsibility applies not only to commercial organizations, but also to all actors whose actions affect the environment and society (Invernizzi, 2017: 1354). So social responsibility must rotate between generations, because the actions of one generation have consequences for the next generation (Folkens, 2019: 160).Social responsibility expresses the implicit or internal commitment of managers to act in their personal capacity for the benefit of the group and not for themselves. When the organization acts out of conscience, we can consider it a socially responsible organization (Mondi, 2015: 38). Social responsibility activities may be more human or charitable for municipalities, especially as their main goal is not to be profit-oriented and also that their duties are somewhat closer to the nature of social responsibility activities (Yarimoglu et al., 2015: 75). Researchers have developed several definitions of the concept of social responsibility, and no single definition has been defined for them, among which we mention the following: Peter Drucker (1977) pointed out in the definition of social responsibility as: "the organization's commitment to the society in which it operates." This definition formed the cornerstone of subsequent studies and opened the door in wide for studying this issue in different directions, whereas the World Bank has defined it as "the commitment of the owners of commercial activities to contribute to sustainable development by working with their employees, their families, the local community and society as a whole to improve the standard of living of people in a manner that serves trade and serves development at the same time" (Al-Masoudi, 2019: 37). Or it is a "mandatory activities undertaken by business organizations towards society with the aim of developing and raising the standard of living of their workers and members of the local community" (Dora et al., 2018: 130).

2-2-2- The importance of social responsibility: The topic of social responsibility has gained special importance at the present time, as talk about social responsibility has recently become a familiar phenomenon that can be clearly seen in the titles of local and international conferences and seminars (AlMasoudi, 2019: 40). (Crowther \& Aras, 2008) states that "the fundamental principle of social responsibility is the social contract between all stakeholders of society, and is a fundamental requirement of civil society" (Crowther \& Aras, 2008: 12). The researchers differed in determining the importance of social responsibility and its positive returns on the organizations that adopt it, as it has been demonstrated So (Mitra, 2012) explained that the social responsibility of organizations is one of the main elements in forming the reputation of organizations, participation in realistic and effective strategies to provide social services and enhance the overall reputation of the organization, which facilitates mechanisms manage the organization and increase its ability to attract new customers and increase market share (Mitra, 2012: 4). While (Packer et al., 2019) has clarified the importance of social 
responsibility as a comprehensive term for a set of theories and practices that all realize the following: (A) that organizations bear responsibility for their impact on society and the natural environment. (B) that organizations bear the responsibility for the behavior of others they deal with. (C) business needs to manage its relationships with the wider community, whether for business reasons or to add value to society (Packer et al., 2019: 2).

2-2-3- Social Responsibility Dimensions: It includes the following dimensions:

A- The economic dimension: Organizations may fulfill their social responsibility to avoid economic costs, which is the interference of government authorities in imposing specific prices on the prices of products or services provided by organizations, imposing escalating taxes or increasing workers 'wages by trade unions as a result of the statement of reports on high profits for the organization (Abdul, 2014: 65). So this dimension means, the production of goods and services that society wants at the price that sustains the work and satisfies investors towards it (Hassan, 2015: 33). The main purpose of social responsibility activities is to contribute to the resources of organizations and sustainable development, improve society and protect the environment. These goals can be accepted by both private and public organizations. However, in the private sector, it can be considered more profitable. On the contrary, in the public sector, the implementation of social responsibility can be considered more benevolent (Yarimoglu, 2015: 78).

B- The social dimension: The ethical commitment to stakeholder theory indicates that organizations must ensure the quality of work life for employees (work quality and work kind life) in addition to work standards and equal opportunities. Other evidence also suggests that socially responsible organizations can appear more attractive to potential employees, leading to a competitive advantage and for employees not to be more committed and satisfied with their jobs (Kang, 2018: 27). Social responsibility includes different procedures that reflect the organizations' commitment to community issues, and engaging in social responsibility creates a positive reputation for organizations in society and among internal and external stakeholders (Al Kerdawy, 2018: 4). The condition for the successful implementation of social responsibility by municipalities is not only the development of an appropriate set of socially responsible activities, but also effective communication, and this can happen across municipal channels as well as independent channels. So, by the properly defined communication process, municipalities can also share the benefits of socially responsible activities that they perform and improving reputation is considered one of the most important things (Tetrevova \& Jelinkova, 2019: 4-5).

C- The environmental dimension: Excessive regulatory pressures or government regulations in protecting the environment and food safety impose on organizations the expense of pollution as a true cost, and this means that they absorb external negative impact (Wang, 2017: 112). The researchers note that the expansion of organizations and the unleashing of the greater exploitation of natural resources and the exacerbation of existing social divisions have actively contributed to organizations assuming responsibility for the environmental impacts of their operations (Farias \& Barreto, 2019: 174), (Stehr et al., 2019). The first stage in the process of building environmental social responsibility is based on the environmental policy of the organization, therefore the top management of the organization must be directly interested in adopting this policy, which explains to all stakeholders that the organization is concerned, committed and responsible in order to protect its environmental environment from all effects Negativity that may result from practicing its activities (Muhammad, 2015: 68).

D- The ethical dimension: The ethical dimension can be referred to as the responsibility of the organization to deal according to ethical standards and principles, when the organization takes into account the ethics in its decisions and dealings, it will surely do what is right and fair and will avoid as much as possible to harm the various groups of society and the wrong decisions against them (Sharif, 2018: 74). The ethical organization relies on three important pillars: individual ethics, leadership ethics, systems and infrastructure for the organization (Mahmoud, 2011: 53). In developed and several developing countries, the demand for the development of socially responsible ethical behavior by all types of economic entities is greater than ever before. However, public authorities can also play an important role in supporting socially responsible ethical behavior among other economic entities (Tetrevova \& Jelinkova, 2019: 2). The ethical dimension should make it clear that "organizations must protect and improve the interests of others, such as stakeholders and stockholders" (Lin, 2019: 11).

E- The charitable dimension: This dimension can be represented through the activities of donations, gifts and charitable humanitarian assistance to the 
organization, which serve the members of society and are by their nature not profitable, but to achieve basic goals such as issues (fighting poverty, combating illiteracy, preventing diseases, assisting educational, cultural and charitable organizations, encouraging the volunteer work of its employees, etc.) (Attia, 2019: 2930). So some studies place the social responsibility of organizations in the voluntary field entirely, while others see it as mandatory (Van Marrewijk, 2003: 98). From the municipalities point of view, the importance of charitable work is emphasized in determining areas of social responsibility, including social support, health, education, culture, the environment, women's and animal rights, strengthening relationships with citizens, assistance in disaster situations, assistance to the disabled, assistance to orphans, and care elderly people, food aid, free used clothes, Ramadan assistance, ambulance assistance, free introductory courses for students, donation to charitable organizations, placing cats and dogs in shelters, food aid for animals, or animal health controls (Tetrevova \& Jelinkova, 2019: 3-4).

\section{DATA ANALYSIS}

3-1-Analyzing the responses of the research sample: 3-1-1- Analyzing the research sample responses to the independent variable (green training and development):

It is clear from Table (3) the paragraphs according to which a measure was taken for the dimensiongreen training and development, which is (q1-q5).When the arithmetic mean for all paragraphs is higher than the hypothetical mean of (3), as it reached the lowest value (3.237) for paragraph (q5), which means that The researched organization has a deficit in providing the budget and requirements for implementing the green training and development process. As for the highest arithmetic mean, it was allocated to paragraph (q3) with a value of (3.661), which means that the researched department is very interested in the field ofgreen training and development and gives clear care to determine its needs of training programs that increase the environmental awareness of employees. The mean for the total dimension (green training and development) was (3.493), with a good level, and with a standard deviation of (0.988), in an average level of dispersion and a different coefficient of (0.284), a percentage of dispersion $(28.4 \%)$, and this indicates an appropriate interest inthe research department of the green training and development process is the result of its interest in including environmental-oriented training programs in its annual training plans.

Table (3): Analysis of the responses of the research sample to the independent variable (green training and development)

\begin{tabular}{|c|c|c|c|c|c|c|c|}
\hline $\begin{array}{l}\text { Independent } \\
\text { variable }\end{array}$ & Paragraph sequence & mean & $\begin{array}{l}\text { Standard } \\
\text { deviation }\end{array}$ & $\begin{array}{l}\text { Coefficient } \\
\text { of }\end{array}$ & Evaluation & Precedence & $\begin{array}{l}\text { Importance } \\
\text { ratio }\end{array}$ \\
\hline \multirow{2}{*}{$\begin{array}{l}\text { Green } \\
\text { Training } \\
\text { and } \\
\text { Development }\end{array}$} & $\begin{array}{l}\text { Q1: The Directorate } \\
\text { adopts the principle of } \\
\text { (continuous } \\
\text { environmental training } \\
\text { and development for } \\
\text { all). }\end{array}$ & 3.638 & .894 & 0.245 & good & first & 0.208 \\
\hline & $\begin{array}{l}\text { Q2: The Directorate } \\
\text { provides the best } \\
\text { developments in } \\
\text { preserving the } \\
\text { environment during the } \\
\text { training process, such } \\
\text { as (how to recycle and }\end{array}$ & 3.333 & 1.020 & 0.306 & medial & fourth & 0.190 \\
\hline
\end{tabular}




\begin{tabular}{|c|c|c|c|c|c|c|}
\hline $\begin{array}{l}\text { rely on alternative } \\
\text { energy and increase } \\
\text { green areas ... etc.). }\end{array}$ & & & & & & \\
\hline $\begin{array}{l}\text { Q3: The Directorate } \\
\text { determines its needs for } \\
\text { training programs that } \\
\text { are concerned with } \\
\text { increasing } \\
\text { environmental } \\
\text { awareness } \\
\text { employees. }\end{array}$ & 3.661 & .940 & 0.256 & good & second & 0.209 \\
\hline $\begin{array}{l}\text { Q4: The training and } \\
\text { development programs } \\
\text { approved in the } \\
\text { directorate promote the } \\
\text { equipping of its } \\
\text { employees with skills } \\
\text { that meet the harmony } \\
\text { between the employee } \\
\text { and the environment. }\end{array}$ & 3.598 & .936 & 0.260 & good & third & 0.205 \\
\hline $\begin{array}{l}\text { Q5: The Directorate } \\
\text { provides the budget and } \\
\text { requirements for } \\
\text { implementing } \\
\text { environmental training } \\
\text { and development } \\
\text { programs. }\end{array}$ & 3.237 & 1.153 & 0.356 & medial & Fifth & 0.185 \\
\hline $\begin{array}{l}\text { Total of dimension } \\
\text { green training and } \\
\text { development }\end{array}$ & 3.493 & 0.988 & 0.284 & good & & \\
\hline
\end{tabular}

3-1-2- Analysis of the responses of the research sample to the dependent variable (social responsibility):

A- The economic dimension: It is clear from Table (4) the paragraphs according to which the economic dimension was measured, which is from (q6q10). When the arithmetic mean for all paragraphs is higher than the hypothetical mean of (3), except (q10) which take a lower mean from the hypothetical mean with a simple thing, as it reached $(2,983)$, which means that the answers of the research sample to this paragraph are not homogeneous, and this indicates that the researched department did not use alternative energy sources except in a small way. The highest arithmetic mean was for paragraph (q7) with a value of (3.502), which indicates that the researched directorate and based on the interviews of the directors are concerned with and take into account the quality and safety in providing services to citizens. Andthe mean of the total economic dimension was (3.305), in an average level, and a standard deviation of (0.981), in an average level of dispersion in the answers of the research sample and with a different coefficient of (0.298), in a dispersion ratio (29.8\%), and this indicates a relative affinity in the answers of the search sample results, that came from the nature of work of municipal institutions supervised by the General Directorate of Municipalities as self-financing, which leads them to provide service projects with economic returns that allow them to provide financial allocations to cover their various expenses.

B- The social dimension: It is clear from table (4) the paragraphs according to which the social dimension was measured, which is from (q11-q15), when the arithmetic mean for all paragraphs is higher than the hypothetical mean of (3), as the lowest value (3.090) of paragraph (q12). This confirms the relative lack of interest in the Directorate to provide a work 
environment with acceptable quality standards for employees, and this is evident in the staff offices of lack of interest in the arrangement and office organization and the principles of archiving and correspondence as well as cleanliness and renewing the work environment and coordination with plants. The highest arithmetic mean was for paragraph (q13) with a value of (3.593). This means that the researched department provides training and development courses for employees in order to encourage good practices socially. The mean for the total social dimension was (3.311), in an average level, and with a standard deviation of (1.041), in an acceptable level of dispersion and a coefficient of variance of (0.315) in a dispersion ratio (31.5\%).So, this indicates the dispersion of the answers of the research sample to an acceptable level for this paragraph, and this resulting from a lack of relative satisfaction of the respondents with the terms of this dimension. This is due to the lack of clarity about the commitment of the respondent directorate to provide a good work environment that meets occupational health and safety standards and adopts a culture of social responsibility and work ethics.

C- The environmental dimension: It is clear from table (4) the paragraphs according to which the environmental dimension was measured, which is from (q16-q20), when the arithmetic mean for all paragraphs is higher than the hypothetical mean of (3), as the lowest value (3.197) for paragraph (q19). This means that there is neutrality among the members of the research sample to the extent of achieving this paragraph in the researched directorate, as the directorate is doing its best to create a safe and healthy environment, whether within the directorate or in cities, but there are some individual or group practices with negative environmental effects that are difficult to diagnose and therefore it is Difficult to charge for one reason or another. As for the highest arithmetic mean, it was for paragraph (q16) with a value of (3.412). So this indicates that there is a relative agreement among the members of the research sample in estimating the directorate's interest in this paragraph, due to a note that the researched department publishes educational and awareness posters on rationalizing the use of water and energy and avoiding Waste of public money in addition to holding workshops, seminars or courses in this field adopted by the Information Division in coordination with the relevant departments such as the Environment Department and the Planning and Followup Section in the Directorate. The mean for the total environmental dimension was (3.288), in an average level, and a standard deviation of (0.982), in an average level of dispersion and with a difference coefficient of (0.298), in a dispersion ratio $(29.8 \%)$. This indicates that there is a noticeable interest in the researched directorate in the environmental aspect, and this concern comes from the directorate's duty to supervise the works and projects of cleaning, gardens, parks and red meat slaughterhouses in the governorates which are carried out by the environmental department of the researched directorate and it is the only section in the organizational structure that deals with the environmental side of the work in the Directorate.

D- The ethical dimension: It is clear from table (4) the paragraphs according to which the ethical dimension was measured, which is from (q21-q25). When the arithmetic mean for all paragraphs is higher than the hypothetical mean of (3), as the lowest value (3.305) for paragraph (q24). This is evidence of the impartiality of respondents from the research sample to determine the extent of the directorate's keenness to form committees concerned with ethics, as such committees are often formed when personal problems occur between employees and the duty of the committees in this case is to try to reform between the two parties or resort to the law of discipline of state employees. The highest arithmetic mean, was of paragraph (q22) with a value of (3.661).This indicates a great agreement among the members of the research sample that the directorate confirms and practices the training and development process for employees for the purpose of adopting ethical behaviors in the workplace in light of the laws and regulations in force, including the law of state employee discipline and anti-corruption. The mean for the total ethical dimension was (3.543), in a good level, and with a standard deviation of (0.888). In a good level of dispersion with a different coefficient of (0.251), in a dispersion rate $(25.1 \%)$, which indicates a great interest on the part of the research department in this dimension. Thisinterest came from recognized the importance of the ethical side in daily reactions between the employees and between them and the customers and their managers at work, to create a familiarity and affection that gives a feeling of contentment and thus achieving efficiency in work.

E- Charitable Dimension: It is clear from Table (4) the paragraphs according to which the human or charitable dimension was measured, which is from (q26-q30). When the arithmetic mean for all paragraphs is higher than the hypothetical mean of (3), as the lowest value (3.113) for the paragraph (q30). Which 
means a relative incompatibility between respondents from the research sample about the directorate's interest in achieving the content of this paragraph, this comes because municipal institutions pour their entire effort into providing basic services to citizens in light of financial allocations that are not satisfactory to aspiration as a result of the economic crisis of the country, and that possession of ownership and management humanitarian projects are among their secondary priorities, and coordination with civil society organizations is often accomplished. The highest arithmetic mean was for (q26) with value of (3.768). So this confirms the relatively large interest in this paragraph by the directorate, as the directorate contributes to many projects, campaigns and humanitarian activities with charitable aspects such as donating blood, for example. The mean for the total human or charitable dimension was (3.443), in an average level, and a standard deviation of (0.985), in an average level of dispersion and a coefficient of variance of (0.287), in a dispersion rate $(28.7 \%)$.This indicates that there is a relative interest in the research department in this dimension. And that came from the result of the municipality's job being essentially a humanitarian, charitable, not-for-profit function, but its main goal is to develop society and achieve its welfare and provide all basic services to all individuals and classes of society equally without discrimination.

F- Total Social Responsibility: It is clear from Table (4) the measurement of total social responsibility, as the arithmetic mean of all dimensions has reached values higher than the hypothetical mean of (3), they have reached a minimum value (3.288) for the environmental dimension which means a relative lack of interest in the researched directorate on the environmental side, this weakness of interest may come because of the allocations for annual cleaning are deposited with the governorates within the region's development plan and they are responsible for spending them and implementing related environmental projects in addition to transferring powers to the governorates, which magnifies the role of the Directorate in following up on this activity. As for the highest arithmetic mean, the ethical dimension has been allocated to a value of (3.543), which indicates the Directorate's high interest in the ethical side in its daily dealings when performing its duties in terms of eliminating financial and administrative corruption and even ethical corruption within the directorate and applying the necessary disciplinary laws and instructions against violators and forming committees follow up to verify full compliance with the directives and instructions in force, but the Directorate does not have an ethical code in its administrative system. The mean for the total social responsibility was (3.378), in an average level, and a standard deviation of (0.975), in an average level of dispersion with a coefficient of variation of (0.289), in a dispersion ratio (28.9\%). This indicates that the researched directorate deals moderately with social responsibility, and this of course comes from the nature of the directorate's work as a non-profit service organization whose duties are limited to providing various municipal services to the urban community and assessing those services provided in terms of environmental, social and economic (not wasting public money). As for the ethical, humanitarian or charitable aspects, they are among the activities and basic pillars of the directorate's work in terms of daily moral dealings, away from financial and administrative corruption, and the human and charitable aspects appear more prominent in natural disasters or wars and the like. But the directorate needs to pay more attention to implementing the dimensions of social responsibility in its work.

Table (4): Analysis of responses of the research sample to the dependent variable (social responsibility)

\begin{tabular}{|l|l|l|l|l|l|l|l|}
\hline dimension & Paragraph sequence & mean & $\begin{array}{l}\text { Standar } \\
\mathbf{d} \\
\text { deviatio } \\
\mathbf{n}\end{array}$ & $\begin{array}{l}\text { Coefficie } \\
\text { nt of } \\
\text { variatio } \\
\mathbf{n}\end{array}$ & $\begin{array}{l}\text { Evaluati } \\
\text { on }\end{array}$ & $\begin{array}{l}\text { Precede } \\
\text { nce }\end{array}$ & $\begin{array}{l}\text { Importa } \\
\text { nce ratio }\end{array}$ \\
\hline \multirow{2}{*}{$\begin{array}{l}\text { The } \\
\text { economic } \\
\text { dimension }\end{array}$} & $\begin{array}{l}\text { Q6: The Directorate guarantees } \\
\text { transparency and openness in its service } \\
\text { work. }\end{array}$ & 3.485 & .929 & .266 & medial & second & 0.210 \\
\cline { 2 - 8 } & $\begin{array}{l}\text { Q7: The directorate takes into account the } \\
\text { quality and safety of services provided to } \\
\text { citizens. }\end{array}$ & 3.502 & .966 & .275 & good & third & 0.211 \\
\hline
\end{tabular}




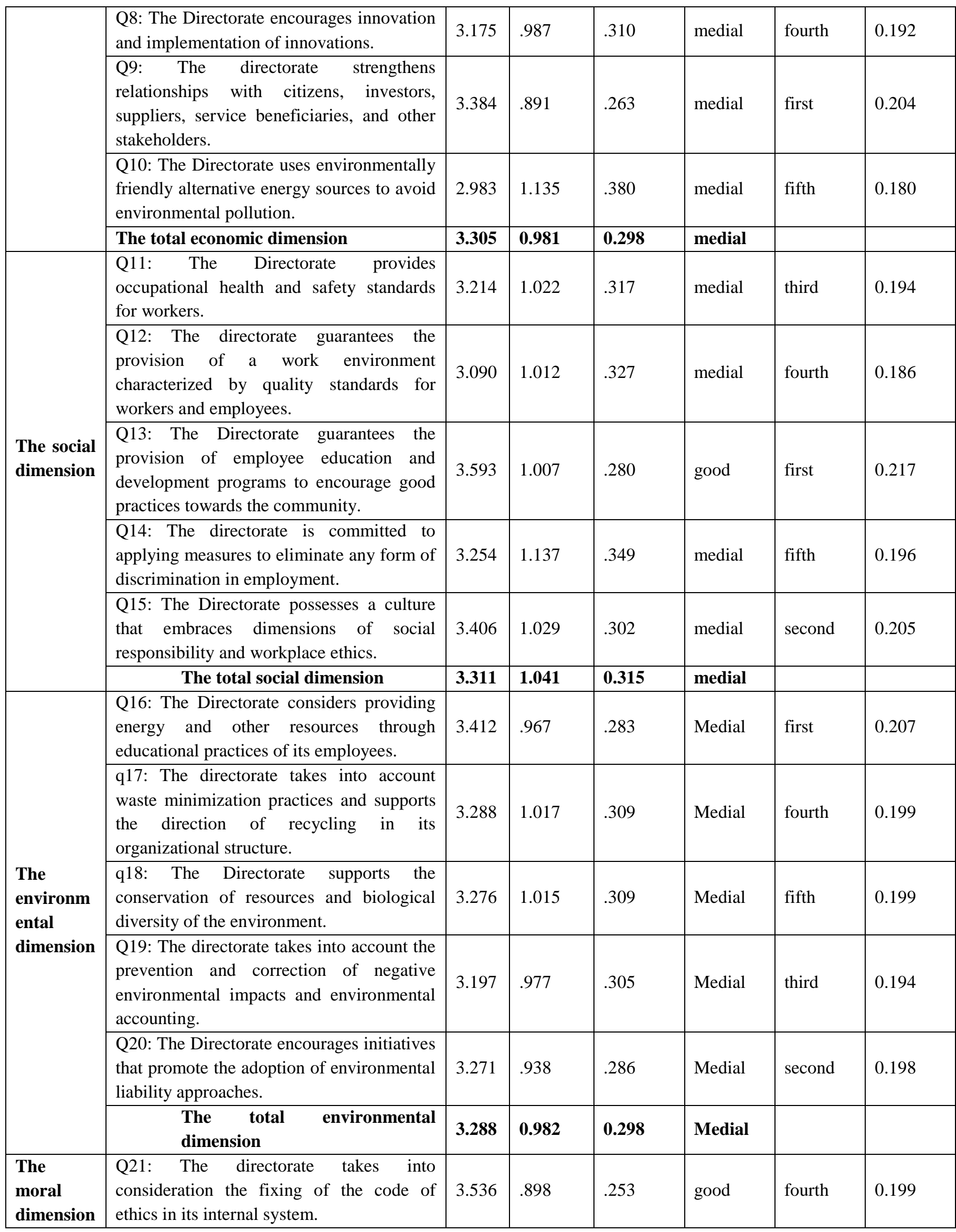




\begin{tabular}{|c|c|c|c|c|c|c|c|}
\hline & $\begin{array}{l}\text { q22: The directorate emphasizes training } \\
\text { and developing employees to adopt ethical } \\
\text { behaviors. }\end{array}$ & 3.661 & .838 & .228 & Good & first & 0.206 \\
\hline & $\begin{array}{l}\text { q23: The Directorate considers the policy } \\
\text { of ethical reporting and ethical review } \\
\text { among employees. }\end{array}$ & 3.587 & .868 & .241 & Good & third & 0.202 \\
\hline & $\begin{array}{l}\text { q24: The Directorate is keen on forming } \\
\text { committees concerned with ethics or } \\
\text { providing communications such as the } \\
\text { hotline for whistle-blowers. }\end{array}$ & 3.305 & .975 & .295 & Medial & fifth & 0.186 \\
\hline & $\begin{array}{l}\text { Q25: The Directorate appreciates and } \\
\text { respects the ethical standards adopted by } \\
\text { society. }\end{array}$ & 3.627 & .864 & .238 & Good & second & 0.204 \\
\hline & Total ethical dimension & 3.543 & 0.888 & 0.251 & Good & & \\
\hline & $\begin{array}{l}\text { q26: The directorate supports humanitarian } \\
\text { activities and contributions, both inside and } \\
\text { outside the directorate (for example, blood } \\
\text { donation). }\end{array}$ & 3.768 & .927 & .246 & Good & first & 0.218 \\
\hline & $\begin{array}{l}\text { q27: The Directorate encourages giving, } \\
\text { sponsoring and volunteering in charitable } \\
\text { activities in the community. }\end{array}$ & 3.553 & 1.016 & .285 & Good & second & 0.206 \\
\hline $\begin{array}{l}\text { Charitabl } \\
\text { e } \\
\text { dimension }\end{array}$ & $\begin{array}{l}\text { q28: The directorate supports staff } \\
\text { volunteering to carry out charitable and } \\
\text { humanitarian activities in their local } \\
\text { communities. }\end{array}$ & 3.446 & .987 & .286 & Medial & third & 0.200 \\
\hline & $\begin{array}{l}\text { q29: The Directorate supports cooperation } \\
\text { with non-profit organizations such as civil } \\
\text { society organizations. }\end{array}$ & 3.339 & .993 & .297 & Medial & fourth & 0.193 \\
\hline & $\begin{array}{l}\text { Q30: The Directorate undertakes ownership } \\
\text { and management of humanitarian projects } \\
\text { that support community preservation and } \\
\text { societal cultural heritage such as } \\
\text { (orphanages or heritage markets). }\end{array}$ & 3.113 & 1.004 & .322 & Medial & fifth & 0.180 \\
\hline & Total charitable dimension & 3.443 & 0.985 & 0.287 & Medial & & \\
\hline To & al social responsibility & 3.378 & 0.975 & 0.289 & Medial & & \\
\hline
\end{tabular}

\section{3-2- testing the correlation between the search variables and their dimensions:}

From Table (5), which shows the test values of the correlation relationship between the independent variable (green training and development) and the dependent variable (social responsibility), there is an association between the training and green development variable and the social responsibility variable, as it reached (Pearson Correlation) (0.685) Good at the level of significance (0.01) and the value of (Sig.) (0.000).As shown in Table (5) also, there is an association between the variable of green training and development and all dimensions of social responsibility, as the value of (Pearson Correlation) reached (0.597) for the economic dimension, (0.658) for the social dimension, (0.620) for the environmental dimension and (0.561) for the ethical dimension and (0.595) for the charitable dimension, with a good correlation level at the level of significance (0.01) and the value of (Sig.) (0.000) for all dimensions. We can explain that relationship with (that the targeted and objective training and development plans or programs adopted by the research organization for knowledge development and develop the human resource capabilities regarding the issue of social responsibility, will definitely be greatly reflected in improving the performance and commitment of employees and 
managers towards the concept of social responsibility and its dimensions.Thus achieving the goals of the organization, which are mainly social service goals, not for profit).

Table (5) correlation between the main search variables and sub-dimensions

\begin{tabular}{|c|c|c|c|c|c|c|c|}
\hline $\begin{array}{l}\text { Independent } \\
\Downarrow \text { ariable }\end{array}$ & $\begin{array}{l}\text { Dependent } \\
\text { variable } \\
\text { and its } \\
\underset{\rightarrow}{\text { dimensions }}\end{array}$ & $\begin{array}{l}\text { economic } \\
\text { dimension }\end{array}$ & $\begin{array}{l}\text { social } \\
\text { dimension }\end{array}$ & $\begin{array}{l}\text { environmental } \\
\text { dimension }\end{array}$ & $\begin{array}{l}\text { ethical } \\
\text { dimension }\end{array}$ & $\begin{array}{l}\text { Charitable } \\
\text { dimension }\end{array}$ & $\begin{array}{l}\text { Social } \\
\text { Responsibility }\end{array}$ \\
\hline \multirow{2}{*}{$\begin{array}{l}\text { Green } \\
\text { Training } \\
\text { and } \\
\text { Development }\end{array}$} & $\begin{array}{l}\text { Pearson } \\
\text { Correlation }\end{array}$ & $.597 * *$ & $.658 * *$ & $.620 * *$ & $.561 * *$ & $.595 * *$ & $.685^{* *}$ \\
\hline & $\begin{array}{l}\text { Sig. } \\
\text { tailed })\end{array}$ & .000 & .000 & .000 & .000 & .000 & .000 \\
\hline
\end{tabular}

(**) Moral with significance level (0.01).

\section{3-3- testing the effect relationship between the two variables and the dimensions of the research:}

Table (6) shows the results of the effect of green training and development on social responsibility using the simple linear regression model. At the aggregate level, the results of the impact test betweengreen training and development and social responsibility show a significant influence as the value of (sig.) Reached (0.000) at the level of Significant (0.01), and the calculated (F) value of (154.644) is greater than (Table F) of (1.96), which confirms the significance of the effect test. The impact factor has reached $(\mathrm{B}=0.614)$, meaning that increasing one unit of green human resource management practices leads to an increase in social responsibility by (61.4\%), As for the interpretation (R2) it reached (0.469), meaning that green training and development activities explain (46.9\%) of social responsibility and $(53.1 \%)$ are interpreted by other factors that are not included in the model or from random errors, and this corresponds to the main hypothesis of the research, whose content (there is Significant effect of green training and development activities on social responsibility), resulting from the reflection of these activities on the nature and function of work and the socially responsible organizational activity. As for the sub-dimensions, the results of the impact test between the green training and development variable and the dimensions of social responsibility (economic dimension, social dimension, environmental dimension, ethical dimension and charitable dimension) showed that there is a significant effect, as the value of (sig.) Reached (0.000) at the level of significance (0.01) for all dimensions, and the calculated value of (F) was $\{(96,800),(133,287),(109,252),(80,357),(95,762)\}$ respectively, which is greater than the $(F)$ tabular of $(1.96)$ which confirms Impact test effect. There is an advantage for the influence and impact of the green training and development variable on the social dimension of social responsibility, as the value of the impact factor $(B=0,704)$ explains ( $\mathrm{R} 2=0.432)$ of the variance in social responsibility.We can explain this effect by (that the organization's interest in green training and development activities and programs in the process of setting goals and green environmental decision-making will contribute to knowledge development and broadening self-awareness of environmental risks, and thus this will reduce the harmful effects resulting from the activities of the organization and this will certainly be reflected on social responsibility, and its dimensions.Because it will improve the quality of social services provided to citizens, which are essentially non-profit services aimed at community development and welfare). On this basis, it is possible to accept the main research hypothesis and the sub-hypotheses that derive from it. 
Table (6): The effect relationship between the two main research variables and sub-dimensions

\begin{tabular}{|c|c|c|c|c|c|c|}
\hline $\begin{array}{l}\text { Independent } \\
\text { variable }\end{array}$ & B & $\mathbf{R}^{2}$ & $\mathbf{F}$ & Sig. & Significance & $\begin{array}{l}\text { Dependent } \\
\text { variable and } \\
\text { its dimensions }\end{array}$ \\
\hline \multirow{6}{*}{$\begin{array}{l}\text { Green } \\
\text { Training and } \\
\text { Development }\end{array}$} & 0.601 & 0.356 & 96.800 & 0.000 & $\begin{array}{l}\text { Significantly } \\
\text { indicated }\end{array}$ & $\begin{array}{l}\text { economic } \\
\text { dimension }\end{array}$ \\
\hline & 0.704 & 0.432 & 133.287 & 0.000 & $\begin{array}{l}\text { Significantly } \\
\text { indicated }\end{array}$ & $\begin{array}{l}\text { social } \\
\text { dimension }\end{array}$ \\
\hline & 0.642 & 0.384 & 109.252 & 0.000 & $\begin{array}{l}\text { Significantly } \\
\text { indicated }\end{array}$ & $\begin{array}{l}\text { environmental } \\
\text { dimension }\end{array}$ \\
\hline & 0.525 & 0.315 & 80.357 & 0.000 & $\begin{array}{l}\text { Significantly } \\
\text { indicated }\end{array}$ & $\begin{array}{l}\text { ethical } \\
\text { dimension }\end{array}$ \\
\hline & 0.600 & 0.354 & 95.762 & 0.000 & $\begin{array}{l}\text { Significantly } \\
\text { indicated }\end{array}$ & $\begin{array}{l}\text { Charitable } \\
\text { dimension }\end{array}$ \\
\hline & 0.614 & 0.469 & 154.644 & 0.000 & $\begin{array}{l}\text { Significantly } \\
\text { indicated }\end{array}$ & $\begin{array}{l}\text { Social } \\
\text { Responsibility }\end{array}$ \\
\hline
\end{tabular}

\section{DISCUSS THE RESULTS:}

The research results show, in general, that the GeneralDirectorate of Municipalities deals good with its green training and development activities in its administration and job programs, this result from the directorate care in develop its employees.But they do not fall within the framework of the concept of green training and development explicitly, so that the Directorate or its managers and employees do not have the knowledge or scientific or academic knowledge towards this concept and its importance. Therefore, this activity cannot be realistically touched within the various training activities of the directorate or within its activities. Also, the results of the research indicate that the activities ofgreen training and development of the directorate have reflected on the performance of managers and employees positively towards their responsibility towards society, although there is also no accurate scientific knowledge among the directorate members towards the concept of social responsibility, its importance and its dimensions. However, the directorate's scope of work and its basic duties as a social, not-for-profit organization makes it a responsible and direct orientation towards community service and achieving its welfare. Therefore, as a result of the correlation and moral impact of green training and development activities and their positive reflection on social responsibility, the directorate must include the concept of these two variables in its service work and training activities because of their high importance in achieving the satisfaction of the beneficiaries of the service and the satisfaction of employees and thus achieving the satisfaction of other stakeholders.

\section{CONCLUSIONS AND RECOMMENDATIONS}

\section{5-1- Conclusions:}

It is clear from the research results that the GeneralDirectorate of Municipalities deals well with green training and development activities in its administrative and employment dealings, and this is a result of the directorate's interest in developing and raising the efficiency of its employees. However, the lack of academic knowledge and scientific documentation of the two research variablesand their dimensions made them unclear and unknown to managers and employees in the directorate, which gave an apparent impression of the existence of a deficiency in the importance of this activity for the development of human resources in the directorate, which reflects positively on building a socially responsible administration. Also, the directorate deals above average with social responsibility, and this is a result of the nature of the directorate's work as a nonprofit service organization whose duties are limited to providing municipal services to all segments of society, 
but the ethical, humanitarian or charitable aspects are among the activities and basic pillars of the directorate's work in terms of daily ethical dealings with the citizens. And the directorate has a high interest in (ethical dimension) of social responsibility in an effort to eliminate financial and administrative corruption and even ethical corruption within the directorate and the application of laws and disciplinary instructions necessary for violators. While (the environmental dimension) came in the last rank of the directorate's interest, and it seems that this is due to the transfer of powers and allocations to the governorates, including cleaning works, waste recycling projects and the establishment of gardens and parks. The results also showed a significant correlation between green training and development and social responsibility in all its dimensions. As well as a significant impact relationship between green training and development and social responsibility in all its dimensions.

\section{5-2- Recommendations:}

Based on the findings, we see the necessity for the GeneralDirectorate of Municipalities to integrate green SOURCES training and development activities in the administrative development process for human resources, because of its positive role in raising awareness of environmental conservation, reducing costs and developing skills. And the importance of it interest also in applying the concept of social responsibility in the functional and administrative process and including it in the directorate's message, vision and its future plans, because of its positive role in improving the reputation of the directorate and achieving the satisfaction of employees and citizens. Therefore it should invest the positive relationship between green training and development and social responsibility in the directorate to focus on improving the quality of public services provided to citizens and improving the environment and achieving welfare for employees and society. So it has to attention to the inclusion of concepts of social responsibility in the training programs of the Directorate and the promotion of these programs with competent trainers and the necessary requirements and the inclusion of employees and managers in it to achieve its purpose and increase the level of its application.

1- Abd, Degla Abdul-Hussein (2014), (Features of the Conceptual Framework for Accounting for Social Responsibility in Iraqi Economic Units), $\mathrm{PhD}$ thesis in Accounting (Unpublished), College of Administration and Economics, University of Baghdad.

2- Abdul Moktadir, Md. \& Ali, Syed Mithun \& Paul, Sanjoy \& Kabir, Golam (2019), (Antecedents for greening the workforce: implications for green human resource management), International Journal of Manpower, DOI: 10.1108/IJM-07-2019-0354, p.p. 1-35.

3- Al Masoudi, Ikhlas Ayesh Shneichel (2019), (The Role of Social Responsibility in Organizational Performance), Higher Diploma Research (Unpublished), College of Administration and Economics, University of Baghdad.

4- Al Kerdawy, Mostafa Mohamed Ahmed (2018), (The Role of Corporate Support for Employee Volunteering in Strengthening the Impact of Green Human Resource Management Practices on Corporate Social Responsibility in the Egyptian Firms ), European Management Review, (2018), DOI: 10.1111/emre.12310, p.p: 1-17.

5- Al-Sakarneh, Muhammad Ihsan (2017), (The Impact of Green Human Resources Management Practices on Differentiation Strategy - Creativity of Human Resources is a Modified Variable), Unpublished Master Thesis, College of Business, Middle East University, Amman.

6- Al-Zubaidi, Ghani Dahham (2016), (The role of green human resource management practices in achieving environmental citizenship requirements - field research at the General Company for Vegetable Oils), Journal of Economic and Administrative Sciences, Volume (22), No. (89) of 2016, Baghdad .

7- Attia, Safaa Ibrahim (2019), (Auditing of social responsibility to achieve the best use of investment funds), PhD thesis in Legal Accounting (unpublished), Higher Institute of Accounting and Financial Studies, University of Baghdad.

8- Crowther, D. \& Aras, G. (2008), (Corporate Social Responsibility), $1^{\text {st }}$ edition, Bookboon.com, Available online: http://lib.bvu.edu.vn/bitstream/ TVDHBRVT/15839/1/Corporate-Social-Responsibility.pdf (accessed on 9 February 2018). 
9- Dora, Omar Muhammad and Al-Tijani, Muhammad Othman Al-Rashid and Al-Yafi, Salem Mohammed (2018), (The exercise of the dimensions of social responsibility and its impact on the performance of companies and petrochemicals), Journal of Economic, Administrative and Legal Sciences, Arab Journal of Science and Research Publishing, No. 6, Volume 2, p.p. 124-144.

10-Drucker, Peter F. (1977), (An Introductory View of management), Harper's college Press, U.S.A.

11-Farias, A. L. \& Barreto, N. L. (2019), (CSR Applied to Socio-Environmental Risks in the Supply Chain: Brazilian's Initiatives Against Slave Labor and Illegal Deforestation), Chapter in book: Corporate Social Responsibility in Brazil - The Future is Now, Springer International Publishing AG, part of Springer Nature 2019, https://doi.org/10.1007/978-3319-90605-8 3.

12-Folkens, L., \& Schneider, P. (2019), (Social Responsibility and Sustainability: How Companies and Organizations Understand Their Sustainability Reporting Obligations), Chapter in book: Social Responsibility and Sustainability,159-188, doi:10.1007/978-3-030-03562-4_9.

13-Formánková, Sylvie; Trenz, Old`rich ; Faldík, Old`rich ; Kolomazník, Jan and Sládková, Jitka (2019), (Millennials' Awareness and Approach to Social Responsibility and Investment-Case Study of the Czech Republic), Sustainability Journal, 11, 504; doi:10.3390/su11020504, www.mdpi.com/journal/sustainability.

14-Hassan, Mohamed Ibrahim (2015), (Dimensions of Social Responsibility and its Implications for the Insurance Industry), Research diploma equivalent to an MSc in Insurance (unpublished), Higher Institute of Accounting and Financial Studies, University of Baghdad.

15-Invernizzi DC, Locatelli G, Brookes NJ (2017), (Managing social challenges in the nuclear decommissioning industry: a responsible approach towards better performance). Int. J. Proj. Manag. Soc. Resp., Management of Megaprojects. 2017-10-01, 35(7):1350-1364. https://doi.org/10.1016/j.ijproman.2016.12.002.

16-Ismail, Ammar Fathi Mousa and Al-Bardan, Muhammad Fawzi Amin (2017), (The Role of Green Human Resources Management Practices in Supporting Environmental Organizational Citizenship Behaviors), published research, Sadat City University.

17-Jabbar, Muhammad Hassan \& Abid, Muhammad (2015), (A Study of Green HR Practices and Its Impact on Environmental Performance: A Review), Magnt Research Report, Vol.3, No.4 .

18-Jain, A. (2016), (Green Human Resource Management Concept in Indian Industries), International Journal of Multidisciplinary Allied Research Review and Practices, 3 (7),p.p. 171 - 181.

19-Kang, William Il-kuk (2018), (Sign of 'Cross-Vergence' in Global HRM-CSR? The UK and Japan Compared), Chapter 3 in book: Human Resource Planning for the 21st Century, intechopen, http://dx.doi.org/10.5772/intechopen.78400.

20-Lin, Li-Wen (2019), (Mandatory Corporate Social Responsibility? Legislative Innovation and Judicial Application in China),Forthcoming in American Journal of Comparative Law (March 28, 2019), Available at SSRN: https://ssrn.com/abstract=3361448.

21-Mahdi, Muhammad Falih Hamza (2018), (Green Human Resources Practices in Sustainable Development - Field Research), unpublished Master Thesis, College of Administration and Economics, University of Baghdad.

22-Mahmoud, Ibtisam Ahmad (2011), (The Role of Moral Conduct Codes for Nursing Institutions in Social Responsibility), Higher Diploma Research in Hospital Administration, College of Administration and Economics, University of Baghdad.

23-Manhal, Mohamed Hussein and Al-Karawi, Mohamed Thabet (2019), (Management Ethics and Professional Ethics Director and Employee Manual for Positive Behavior in Organizations), first edition, Dar Al-Fayhaa for Printing, Publishing and Distribution, Beirut.

24-Mashala, Yusuph Lameck (2018), (Green Human Resource Management and Environmental Sustainability in Tanzania: A Review and Research Agenda ), International Journal of Academic Multidisciplinary Research (IJAMR), Vol.(2), Issue (12), p.p. (60-68).

25-Mitra, Rahul (2012), (My Country's Future: A Culture-CenteredInterrogation of Corporate Social Responsibility in India), Journal of Business Ethics, Springer Science + Business Media,DOI 10.1007/s10551-011-0985-8. 
26-Mondi, R. Wayne (2015), (Human Resources Management), Arabic (first) edition, The Library of Lebanon, International Jeweler Publishers, Beirut, in cooperation with Pearson Education - Prentice Hall, New Jersey.

27-Mousa, Sharifa K. \& Othman, Mohammed (2019), (The Impact of Green Human Resource Management on Sustainable Performance in Health Care Institutes : A Conceptual Framework),Clean Production Journal, Volume (243),10 JAN,2020,118595,ELSEVIER.

28-Muhammad, Luay Muhammad Shams al-Din (2015), (Diagnosis of the practice of excluding social responsibility and the obstacles to its application), research diploma equivalent to a master's degree in municipal administration (unpublished), College of Administration and Economics, University of Baghdad.

29-Packer, Helen; Swartz, Wilf; Ota, Yoshitaka and Bailey, Megan (2019), (Corporate Social Responsibility (CSR) Practices of the Largest Seafood Suppliers in the Wild Capture Fisheries Sector: From Vision to Action), Sustainability Journal, 11, 2254; doi:10.3390/su11082254, www.mdpi.com/journal/sustainability.

30-Pinzone, M., Guerci, M., Lettieri, E., Huisingh, D., (2019),( Effects of "green" training on pro-environmental behaviours and job satisfaction: Evidence from the Italian healthcare sector), Journal of Cleaner Production, 226, 221232.

31-Shah, M. (2019), (Green human resource management: development of a valid measurement scale), Business Strategy and the Environment, pp. 1-15, available at: https://doi.org/10.1002/bse.2279.

32-Sherif, Doaa Sadiq (2018), (The Role of Moral Leadership in Promoting Social Responsibility), Master Thesis in Public Administration (unpublished), College of Administration and Economics, University of Baghdad.

33-Stehr, C. \& Dziatzko, N. \& Struve, F. (2019), (Corporate Social Responsibility in Brazil - The Future is Now), Springer International Publishing AG, part of Springer Nature 2019, Switzerland. https://doi.org/10.1007/978-3-319-906058.

34-Teixeira, Adriano Alves \& Jabbour, Charbel Jose Chiappetta \& Jabbour, Ana Beatriz Lopes (2012), (Relationship between green management and environmental training in companies located in Brazil: A theoretical framework and case studies), Journal Production Economics, Vol. 140 .

35-Teixeira, Adriano Alves \& Jabbour, Charbel Jose Chiappetta \& Jabbour, Ana Beatriz Lopes \& Latan, Hengky \& Caldeira, Jorge Henrique (2016), (Green training and green supply chain management: evidence from Brazilian firms), Journal of Cleaner Production,Vol. 116.

36-Tetrevova, Libena \& Jelinkova, Martina (2019), (Municipal Social Responsibility of Statutory Cities in the Czech Republic), Sustainability Journal, 11, 2308, doi:10.3390/su11082308, www.mdpi.com/journal/sustainability.

37-Tiwari, Prakash \& Bangwal,Deepak (2015), (Green HRM - A way to greening the environment), Journal of Business and Management, vol. 17, Issue 12 .

38-Van Marrewijk, M. (2003), (Concepts and definitions of CSR and corporate sustainability: between agency and communion), Journal of Business Ethics, 44(2-3), 95-105.

39-Wang ,George Y. (2017), (Taking Corporate Social Responsibility as Growth Strategy),Chapter(5) in book: Corporate Governance and Strategic Decision Making, For: Emeagwali, Okechukwu Lawrence, IntechOpen, DOI: 10.5772/intechopen.69028. Available from: https:/www.intechopen.com/books/corporate-governance-and-strategicdecision-making/taking-corporate-social-responsibility-as-growth-strategy.

40-Yarimoglu, E.K.; Hacioglu, F.; Gencturk, S.; Kamali Celik, Y \& Sayginer, C. (2015), (A Qualitative Research on Municipalities' Social Responsibility Practices in Izmir City),E-Journal of Yasar University, 10 Special Issue on Social Responsibility Education and Practices,p.p. 75-92. 